\title{
Effect of Ivermectin on the Life Cycle and Larval Fat Body of Culex quinquefasciatus
}

\author{
Stenio Nunes Alves ${ }^{1}$, José Eduardo Serrão ${ }^{2 *}$, Giovani Mocelin ${ }^{1}$ and Alan Lane de Melo ${ }^{3}$ \\ ${ }^{I}$ Programa de Pós-Graduação em Entomologia; Departamento de Biologia Animal; Universidade Federal de \\ Viçosa; Viçosa - MG - Brazil. ${ }^{2}$ Departamento de Biologia Geral; Universidade Federal de Viçosa; 36570-000; \\ Viçosa - MG - Brazil. ${ }^{3}$ Departamento de Parasitologia; Instituto de Ciências Biológicas; Universidade Federal de \\ Minas Gerais; Belo Horizonte - MG - Brazil
}

\begin{abstract}
The present work investigated the behavior, survival rate and lethal effect of 1.5 ppb ivermectin on Culex quinquefasciatus larvae, based on morphological and biological parameters, and possible alterations of their fat body. Changes in the number of eggs/egg mass and length of the larval stage were investigated. For this experiment, 600 larvae of $3^{\text {rd }}$ and $4^{\text {th }}$ instars of the mosquito were tested. The laid eggs were separated and the hatched larvae were counted. Some larvae submitted to $1.5 \mathrm{ppb}$ ivermectin solution were used to prepare samples for histological study. Results obtained showed that ivermectin in a concentration of $1.5 \mathrm{ppb}$ caused paralysis to the larvae with a mortality rate of $73.38 \%$, mobilization of substances stored in the fat body and reduction of the number of egg laid in the adult stage.
\end{abstract}

Key words: Diptera, fat body, insecticide, mosquito, reproductive biology

\section{INTRODUCTION}

Ivermectin is a group of macrocyclical lactones, derived from 22,23-dihydro avermectin B1, with low water solubility that is produced by Streptomyces avermectilis (Burg, et al., 1979; Egerton et al., 1979; Miller et al., 1979; Chabala et al., 1980), being largely used as anti-parasitic in the domestic animals (Aziz et al., 1982; Campbell et al., 1983). Previous studies have shown that the avermectins are lethal for immature and adult stages of some insect orders (Strong and Brown, 1987) and efficient for the control of Culex quinquefasciatus (Freitas et al., 1996). It is not necessary its ingestion, because the contact with the same already is effective in the majority of the cases (Strong, 1993). Seif et al. (1997) observed the sub-lethal effects for some insecticides on Culex pipens larvae and found that Wuchereria brancofti development was prejudiced when insects were exposed to the drugs. Sub-lethal effects of insecticide acts within three categories: feed inhibition, development abnormalities and reproductive disturbances (Strong and Brown, 1987). Sub-lethal effects of avermectins were observed on the reproduction of Rhodnius prolixus (De Azambuja et al., 1985) and on the development inhibition of Chrysomya bezziana and Calliphora vomitoria (Spradbery et al., 1985; Strong, 1986).

In Diptera and Coleoptera, there are reports about water accumulation in the individuals as

\footnotetext{
* Author for correspondence
} 
consequence of the avermectin action suggesting that the drug has interference in the Malpighian tubules and hormones that acts on water balance (Strong, 1993). In addition, mortality and paralysis caused by the ivermectin have been observed in adults of Aedes fluviatilis, Aedes aegypti, Anopheles quadrimaculatus and other mosquitos' species (Consoli et al., 1986; Tesh and Guzman, 1990; Foks et al., 1991; Jones, et al., 1992; Gardner, et al., 1993).

In mosquitoes, the fat body is represented by a board of cells adhered to the body wall at the thorax and abdomen extending itself for the body cavity and surrounding certain organs (Clements, 1996). It is the main organ of intermediary metabolism in insects, functioning as an organ of protein, lipid and carbohydrate storage (Chapman, 1998). The total of carbohydrates and lipid found in the adult arisen from of the stored energy obtained during the larval stage (Clements, 1996).

Strong and Brown (1987) stated that avermectin could affect insect organs such as fat body. The fat body of larvae and adults Diptera has specific functions regarding to the period of insect developmental stage. In this sense, it is the site of proteins synthesis for the haemolymph in larvae and adults, while in adult females, this organ produces the yolk polypeptides, and there are indications, of its involvement in the immune response, because some peptides are produced in the fat body and released into the haemolymph, such as the defensine, a group of compact molecules protease-resistant with 3 or 4 disulphide bounds with direct activity in the immune response against some bacteria, yeast and viruses (Hoffmann et al. 1999; Zanetti et al., 1997). However, little is knows about the effect of the 22,23-dihydroavermectina B1 on the life cycle and fat body of $C$. quinquefasciatus. Hence, the purpose of this work was to study morphological alterations on the larval fat body and on the life cycle of $C$. quinquefasciatus exposed to ivermectin.

\section{MATERIALS AND METHODS}

Sixty groups containing 20 larvae of third and fourth instar of Culex quinquefasciatus were placed in plastic containers. Thirty groups were exposed to $100 \mathrm{ml}$ of $1.5 \mathrm{ppb}$ water solution of ivermectin $\quad\left[\left(22,23\right.\right.$-dihydroavermectin $\quad B_{1}$
(Ivermectin ${ }^{\mathrm{TM}}$ Ivomec)] during $30 \mathrm{~min}$, which were termed experimental group. The other thirty groups were used as control group, which were placed in containers with water without ivermectin. Larvae exposed to ivermectin were washed in water and transferred to plastic containers with water. The larvae were feed on ration routinely used to mice nourishment. Five couples from the control and ivermectin exposed groups were placed in cages and fed with $10 \%$ honey. The females had spotted nothura (Nothura minor) in natura as blood source. The mosquitoes were maintained at $26 \pm 1{ }^{\circ} \mathrm{C}$ with $12 \mathrm{~h}$ photoperiod and the following features were evaluated: survival, the number of egg masses produced, the number of eggs/egg mass, duration of egg stage, duration of larval stage and duration of pupal stage. Data were submitted to $t$-student test, with the level of significance set at $1 \%$.

For morphological analyses, twenty larvae of third and fourth instar of $C$. quinquefasciatus were placed in plastic containers containing $100 \mathrm{ml}$ of $1.5 \mathrm{ppb}$ of 22,23-dihydroavermectin $\mathrm{B}_{1}$ (Ivermectin $^{\text {TM }}$ Ivomec) during $30 \mathrm{~min}$. An identical number of larvae were used as control group, which were placed in containers with water. Following the exposition to ivermectin solution, survivor larvae were transferred to $4 \%$ paraformaldehyde at phosphate buffer $0.1 \mathrm{M}, \mathrm{pH}$ 7.2 for $24 \mathrm{~h}$. The larvae were dehydrated in an ethanol series, embedded in methacrylate resin (Leica). The $4 \mu \mathrm{m}$ sections were submitted to the following staining procedures: (1) PAS for neutral polysaccharides and gluconjugates,

bromophenol blue for total proteins, (3) Nile blue for lipids, (4) $1 \%$ toluidine blue-borax and (5) Methyl green pyronin for cell death. The staining procedures were carried out as described by Pearse (1968), following small adaptations for use in resin.

\section{RESULTS}

Larval mortality was 30.78 and $71.71 \%$ for control and experimental groups, respectively, showing significant differences between the groups $(t=$ 7.86; $\mathrm{dl}=58 ; \mathrm{p}<0.001)$. All specimens that died from the experimental group showed progressive paralysis. For 169 adults from experimental group, $55.88 \%$ were females, while the control group had 415 adults with $53.37 \%$ females. Variance analysis 
showed effect of ivermectin exposure on adult emergence $(F=73.12 ; \mathrm{p}<0.001)$ without sex interaction $(\mathrm{F}<0.001 ; \mathrm{p}=0.9896)$.

Mated females produced three egg masses for experimental group with a variation from 84 to 134 eggs/egg mass totaling 319 eggs. Control group produced six egg masses with a variation from 94 to 114 eggs/egg masses totaling 607 eggs. Statistical test was performed by $t$-student test with separated variances for the number of eggs/egg mass between control and experimental groups, because the homogeneity tests for variances were significant, showing variances differences between the groups $(t=-0.343 ; \mathrm{dl}=2.32 ; \mathrm{p}=0.762)$.

Data on duration of egg stage, larval stage and pupal stage are placed in Table 1 with respective statistical test, which showed no significant differences between control and experimental groups.

Table 1 - Biological parameters after oviposition of Culex quinquefasciatus females arisen from larvae exposed to $1.5 \mathrm{ppb}$ of ivermectin (experimental group) and not exposed (control group).

\begin{tabular}{ccc|c|c|c}
\hline Biological parameters & Control group & Experimental group & $\boldsymbol{t}$ & $\boldsymbol{d} \boldsymbol{f}$ & $\boldsymbol{p}$ \\
\hline Duration of egg stage (days) & 3.83 & 3.67 & 0.333 & 7 & 0.748 \\
Duration of larval stage (days) & 11.17 & 10.67 & 0.284 & 7 & 0.785 \\
Duration of pupal stage (days) & 5.17 & 4.00 & 1.99 & 7 & 0.087 \\
\hline
\end{tabular}

The sections stained with the toluidine blue-borax showed that the fat body followed standard morphological pattern described for other insects, i.e., well developed cells with cytoplasm presenting considerable granulation (Figure 1). Histochemical tests showed that these granules consisted of lipids, carbohydrates and proteins. However, the fat body cells of larvae exposed to the ivermectin solution showed a finer granulation in the cytoplasm (Figure 2). The histochemical tests had shown that these granules presented the same constitution of those more homogenous observed in the fat body cells of control larvae, i.e., lipids, proteins and carbohydrates (Figs 3 - 5). The tests with methyl green-pyronin did not show significant differences in the rate of cell death, between the control and ivermectin exposed larvae being observed few cells with aspect of death in both groups. During the analyses of the fat body, other organs were observed and variations of the ivermectin exposition were not observed. In this sense, the midgut presented a well developed single epithelium of columnar cells with evident striated border. The peritrophic membrane was always present forming the endo and ectoperitrophic spaces, which showed different aspects suggesting that the peritrophic matrix was not affected by ivermectin exposure. Malpighian tubules were formed by cells with evident spherical nucleus containing chromatin some condensed, however, was not observed accumulation of any substance in its lumen, which was narrow. An interesting result was the presence, in some ivermectin exposed larvae, of a high amount of bacteria distributed by practically the entire body cavity of the insect.

\section{DISCUSSION}

The high mortality rate found for ivermectin exposed larvae was in agreement with Spradbery et al. (1985) and Strong (1986) who found inhibition of pupation and adult development in Chrysomya bezziana and Calliphora vomitoria exposed to sub-lethal doses of ivermectin. The development of the $F_{1}$ generation from control and ivermectin exposed larvae agreed with the results found by Vianna et al. (1996) with an aquatic cycle between 8 to 48 days. However, in the ivermectin exposed larvae, $F_{1}$ generation shortened about 1 day its development from egg to adult, suggesting that the ivermectin exposure of parental generation may cause a rapid development to avoid the environment stress. Ivermectin caused paralysis in Culex quinquefasciatus larvae, as observed by Freitas et al. (1996) which could be results of the activation of chlorine canals as suggested by Bloomquist (1996). Ivermectin binds to GABA, which increase the possibility of the GABAa in activating chloride canals of postsynaptic membranes. This promotes an influx of chloride ion and irreversible hyperpolarization with consequent inhibition of transmission signals (Campbell, 1985; Turner and Schaeffer, 1989). 

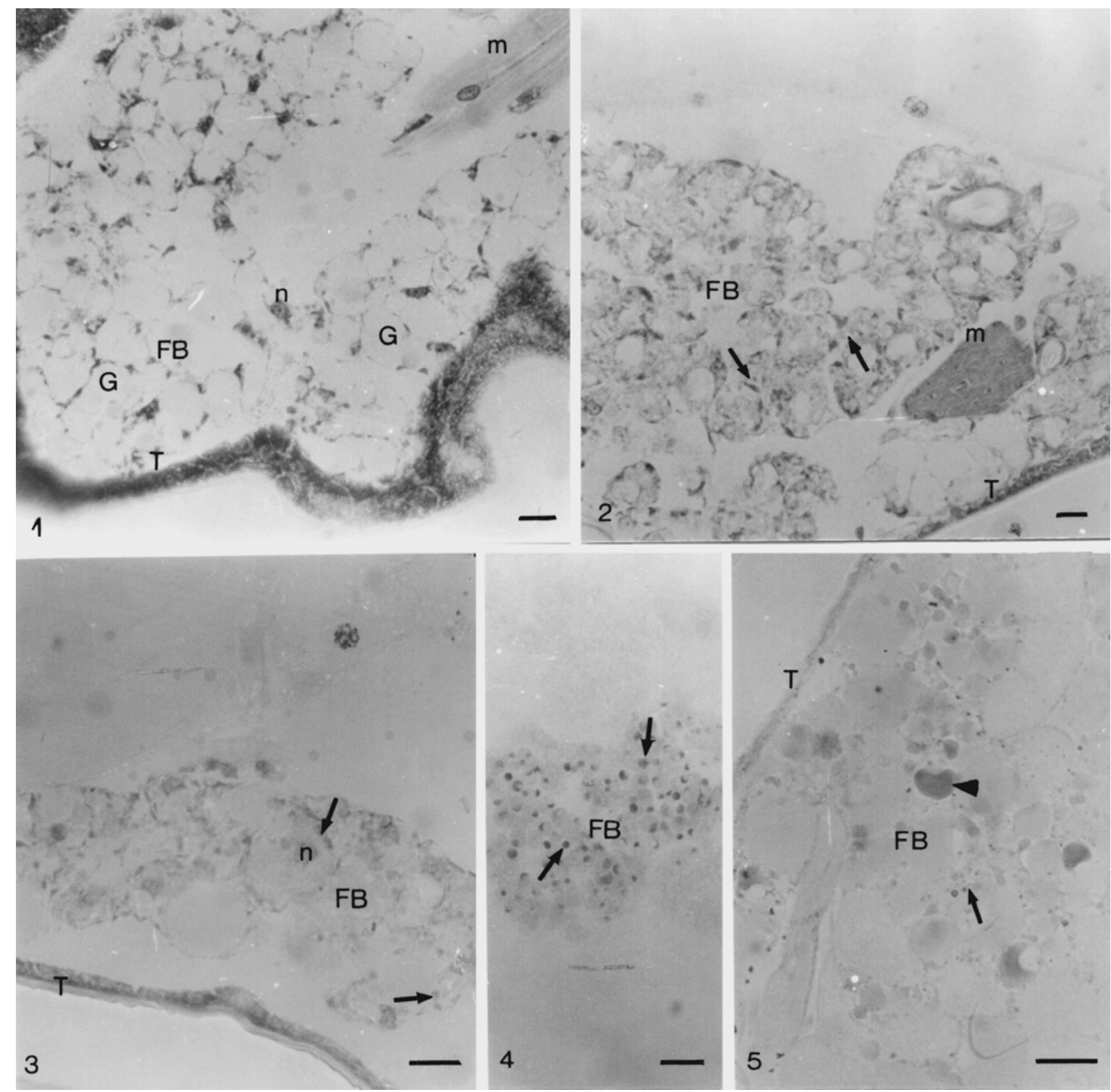

Figures 1 - 5 - Fat body (FB) of third instar larvae of Culex quinquefasciatus.1. Control larvae showing fat body cells filled with large and homogeneous granules $(\mathrm{G})$. Toluidine blue. 2. Ivermectin exposed larvae showing fat body cells with cytoplasm presenting fine granulation (arrows). Toluidine blue. 3. Ivermectin exposed larvae showing fat body cells with peripheral lipid droplets (arrows). Nile Blue. 4. Protein granules (arrows) into the fat body cells of ivermectin exposed larvae. Bromophenol blue. 5. PAS reaction in the fat body of ivermectin exposed larvae showing positive reaction in both larger (arrowhead) and little (arrows) granules. $\mathrm{m}$ - muscle; $\mathrm{n}$ - nucleus; $\mathrm{T}$ - integument. Bars $=15 \mu \mathrm{m}$.

Ivermectin also can bind to other specific ion canals directly, following a disturbance of the electric balance. However, action of the ivermectin may be associated with neurotransmitter release in conjunction with the GABA antagonist, probably contributing for excitatory signals of poisoning (Turner and Schaeffer, 1989; Bloomquist, 1996).

In the present study, the majority of the larvae of C. quinquefasciatus exposed to the $1.5 \mathrm{ppb}$ solution of ivermectin presented ataxia, followed by death, suggesting binding of this insecticide to 
the GABA with consequent lethal action for $C$. quinquefasciatus, which agreeed with results obtained by Freitas et al. (1996). Therefore, the ivermectin may be acting in the hyperpolarization of the fat body cell membranes inhibiting lipid, carbohydrate and/or protein uptake making with that these cytoplasmic inclusions became minors. The appearance of these small inclusions in the fat body may be due to, also, for larval stress when exposed to the ivermectin solution, showing a signal of the mobilization of these reserve for the energy production in a possible process of drug detoxification, because the resistance of some mosquitoes larvae to insecticides has been suggested as result of detoficant enzymes action (Georghieu and Pateur, 1978; Kao et al., 1984). Future studies on the metabolism of the fat body may be able to indicate if the enzymatic system is being affected, because protein and lipid synthesis occurs in the larval fat body of the fourth instar mosquitoes larvae (Timmermann and Biegel, 1999).

This possible release of energy for the metabolization of the insecticide may be the cause of decreasing in the number of egg mass found in females arisen from ivermectin exposed larvae, because during vitellogenesis, fat body cells suffer changes, passing of storage cells for cells with a high protein synthesis (Raikhel and Lea, 1983, 1987). The vitellin is the major protein of yolk being produced from another protein, the vitellogenin (VG). The synthesis of VG occurs in a short period of time, involving extensive cytological changes of the fat body and ovaries (Valle, 1993). Clements (1996) have pointed out that some increase in cellular size occurs with the accumulation of lipids and glycogen, while the storage of proteins is associated with a considerable increase in the volume of the fat body cells. Decrease in egg production was also observed in Rhodnius prolixus females exposed to ivermectin (De Azambuja et al., 1985).

Involvement of vitellogenesis with the ivermectin can also affect polyamines synthesis in $C$. quinquefasciatus, because this synthesis is one of the first events of the yolk formation in Aedes aegypti (Kogan and Hagedorn, 2000). When the polyamine synthesis suffers reduction, induced experimentally, there are decline in the levels of nucleic acid and proteins, causing abnormal ovary development.

The damage in the larval fat body caused by the exposition to the ivermectin solution may results in damage in the defense system in the adult, since the protein synthesis of this organ is necessary for the production of the defense cells, as the haemocytes (Clements, 1996). Something similar seemed to have occurred in this study, because we frequently observed bacteria proliferation in the larval body cavity, which suggested deficiency of the defense cells in the insects. Therefore, this study showed that ivermectin caused high level of larval mortality and decrease on reproductive performance of adults arisen from ivermectin exposed larvae, suggesting that ivermectin was a drug that could be used for the control of mosquitoes population.

\section{ACKNOWLEDGEMENTS}

Brazilian Research Agency CNPq supported this work. We are grateful to Dr Raul Narciso Carvalho Guedes from Federal University of Viçosa for technical assistance and criticism.

\section{RESUMO}

O presente trabalho verificou o comportamento, sobrevivência e o efeito letal de 1,5 ppb de ivermectina em larvas de Culex quinquefasciatus. As possíveis alterações morfológicas no corpo gorduroso das larvas, no número médio de ovos por postura da fêmea e a duração do período larval foram avaliadas. Na sua execução foram utilizadas 601 larvas de $3^{\circ}$ e $4^{\circ}$ ínstar do mosquito. Após a postura, os ovos foram separados e as larvas eclodidas contadas. Algumas larvas submetidas à solução $1,5 \mathrm{ppb}$ de ivermectina, foram utilizadas para o preparo de amostras para estudos histológicos. Os resultados mostraram que a ivermectina na concentração de $1,5 \mathrm{ppb}$ causou paralisia nas larvas com $73,38 \%$ de mortalidade, mobilização das substâncias estocadas no corpo gorduroso larval e uma diminuição do número de posturas.

\section{REFERENCES}

Aziz, M. A.; Diop, I. M.; Diallo, S.; Lariviere, M. and Porta, M. (1982), Efficacy and tolerance of ivermectin in human onchocerciasis. Lancet, 2, 171-173.

Bloomquist, J. R. (1996), Ion channels as targets for insecticides. Annu. Rev. Entomol., 41, 163-190. 
Burg, R.; Miller, B. M.; Baker, E. E.; Birnbaum, J.; Currie, S. A.; Hartman, R.; Kong, Y. L.; Monaghan, R. L.; Olson, G.; Putter, R. I.; Tunac, J. B.; Wallik, H.; Stapley, E. O.; Oiwa, R. and Omura, S. (1979), Avermectins, new family of potent anthelmintic agents, producing organism and fermentation. Antimicrob. Agents Chemother., 15, 361-367.

Campbell, W. C. (1985), Ivermectin: an update. Parasit. today, 1, 10-16.

Campbell, W. C.; Fisher, M. H.; Stapley, E.O.; AlbersShönberg, G and Jacob, T. A. (1983), Ivermectin: a potent antiparasitic agent. Science, 221, 823-828.

Chabala, J . C.; Mrozik, H.; Tolman, R. L.; Eskola, P.; Lusi, A.; Peterson, L. H.; Woods, M. F.; Fisher, M. H.; Campbell, W. C.; Egerton, J. R. and Oslind, D. A. (1980), Ivermectin, a new broadspectrum antiparasitic agent. J. Med. Chem., 23, 1134-1136.

Chapman, R. F. (1998), The insects: structure and function. $4^{\text {th }}$ ed. Cambridge : Cambridge University Press.

Clements, A. N. (1996), The biology of mosquitoes. London : Chapman and Hall. v. 1.

Consoli, R. A. G. B.; Pereira, J. P.; Silveira, J. N. and Castro, M. M. T. (1986), Suscetibilidade de adultos de Culex quinquefasciatus (Say) e Aedes fluviatilis (Lutz) (Diptera: Culicidae) a diversos inseticidas em laboratório. Rev. Bras. Ent., 30, 79-85.

De Azambuja, P.; Gomes, J. E. P. L.; Lopes, F. and Garcia, E. S. (1985), Efficacy of ivermectin against the bloodsucking insect, Rhodnius prolixus (Hemiptera, Triatominae). Mem. Inst. Oswaldo Cruz, 80, 439-442.

Egerton, J. R.; Oslind, D. A.; Blair, L. S.; Eary, C. H.; Suhayds, D.; Cifelli, S.; Riek, R. F. and Campbell, W. C. (1979), Avermectins, new family of potent anthelmintic agents. Efficacy of the $\mathrm{B}_{1}$ component. Antimicrob. Agents Chemother., 15, 372-378.

Foks, D. A.; McLaughlin, R. E. and Linda, S. B. (1991), Effects of ivermectin (MK-933) on the reproductive rate of Aedes aegypti (Diptera: Culicidae). J. Med. Ent., 28, 501-505.

Freitas, R. M. C.; Faria, M. A.; Alves, S. N. and Melo, A. L. (1996), Effects of Ivermectin on Culex quinquefasciatus larvae. Rev. Inst. Med. Trop. S. Paulo, 38, 111-115.

Gardner, K.; Meish, M. V.; Meek, C. L. and Bivin, W. S. (1993), Effects of ivermectin in canine blood on Anopheles quadrimaculatus, Aedes albopictus and Culex salinarius. J. Amer. Mosq. Control. Ass., 9, 400-402.

Georghieu, G. and Pateur, N. (1978), Electrophoretic esterase patterns in insecticide-resistant and susceptible mosquitoes. J. Econ. Ent., 71, 201-205

Hoffmann, J. A.; Kafatos, F. C.; Janeway, C. A. and Ezekowits, R. A. B. (1999), Phylogenetic perspectives in innate immunity. Science, 284, 1313-1318.
Jones, J. W.; Meish, M. V.; Meek, C. L. and Bivin, W. S. (1992), Lethal effects of ivermectin on Anopheles quadrimaculatus. J. Amer. Mosq. Control Ass., 8, 278-280.

Kao, L. R.; Motoyama, N. and Dauterman, W. C. (1984), Study on hydrolases in various housefly strains and their role in Malathion resistance. Pestic. Biochem. Physiol., 22, 86-92.

Kogan, P. H. and Hagedorn, H. H. (2000), Polyamines, and effects from reducing their synthesis during egg development in the yellow fever mosquito, Aedes aegypti. J. Insect Physiol., 46, 1079-1095.

Miller, T. W.; Chaiet, L.; Cole, D. J.; Flor, J. E.; Goegelman, R. T.; Gullo, V. P.; Kempf, A. J.; Krellwitz, W. R.; Monaghan, R. L.; Ormond, R. E.; Wilson, K. E.; Alabers-Schöenberg, G. and Putter, I. (1979), Avermectins, new family of potent anthelmintic agents, isolation and chromatographic properties. Antimicrob. Agents Chemother., 15, 368-371.

Pearse, A.G.E. (1968), Histochemistry theoretical and applied. $3^{\text {rd }}$ ed. Boston : Little, Brown and Co.

Raikhel, A. S. and Lea, A. O. (1983), Previtellogenic development and vitellogenin synthesis in the fat body of a mosquito: An ultrastructural and immunocytochemical study. Tissue Cell, 15, 281-300.

Raikhel, A. S. and Lea, A. O. (1987), Analysis of mosquito yolk protein by monoclonal antibodies. In: Law, J. and Alan, R. (eds.). Molecular Entomology, New York : Liss Inc. pp. 403-413.

Seif, A. I.; Husseiny, I. M.; Soliman, B. A., Soliman, M. A. and El-Kady, M. A. (1997), Development of Wuchereria bancrofti in Culex pipiens L. (Diptera: Culicidae) exposed in the larval instar to sublethal dosages of insecticides and one insect growth regulator and their influence on reproduction of filaria-infected mosquitoes. J. Egypt. Soc. Parasitol., 27, 843-853.

Spradbery, J. P.; Tozer, R. S.; Drewett, N. and Lindsey, M. J. (1985), The efficacy of ivermectin against larvae of the screw-worm fly (Chrysomya bezziana). Aust. Vet. J., 62, 311-314.

Strong, L. (1986), Ivermectin prevents head eversion in the blowfly Calliphora vomitoria (L.). Experientia, 42, 1295-1296.

Strong, L. (1993), Overview: the impact of ivermectin on pastureland ecology. Vet. Parasit., 48, 3-17.

Strong, L. and Brown, T. A. (1987), Avermectins in insect control and biology: a review. Bull. Entomol. Res., 77, 357-389.

Tesh, R. B. and Guzman, H. (1990), Mortality and infertility in adult mosquitoes after the ingestion of blood containing ivermectin. Amer. J. Trop. Med. Hyg., 43, 229-233.

Timmermann, S. E. and Briegel, H. (1999), Larval growth and biosynthesis of reserves in mosquitoes. J. Insect. Physiol., 45, 461-470. 
Turner, M. J. and Schaeffer, J. M. (1989), Mode of action of ivermectin. In: Campbell, W. C. (ed.). Ivermectin and abamectin. New York : SpringerVerlag. pp. 73-88.

Valle, D. (1993), Vitellogenesis in insects and other groups: a review. Mem. Inst. Oswaldo Cruz, 88, 1-26.

Vianna, E. E. S.; Costa, P. R. P. and Ribeiro, P. B. (1996), Oviposição e longevidade de adultos do Culex quinquefasciatus Say, 1823 (Diptera: Culicidae) em condições ambientais, em Pelotas, RS. Rev. Bras. Parasitol. Vet., 5, 47-52.

Zanetti, M.; Gennaro, R. and Romeo, D. (1997), The Cathelicidium family of antimicrobial peptide precursors: A component of the oxygen - independent defense mechanisms of neutrophils. Ann. N. Y. Acad. Sci., 832, 147-162.

Received: April 29, 2002; Revised: September 19, 2002; Accepted: July 16, 2003. 